\title{
Ranaviruses and reptiles
}

\author{
Wytamma Wirth $^{\text {Corresp.. }}{ }^{1}$, Lin Schwarzkopf ${ }^{2}$, Lee F Skerratt ${ }^{3}$, Ellen Ariel ${ }^{1}$ \\ ${ }^{1}$ College of Public Health, Medical and Vet Sciences, James Cook University of North Queensland, Townsville, QLD, Australia \\ 2 \\ 3 Melbourne Veterinary School, Faculty of Veterinary and Agricultural Sciences, University of Melbourne, Melbourne, Australia \\ Corresponding Author: Wytamma Wirth \\ Email address: wytamma.wirth@my.jcu.edu.au
}

Ranaviruses can infect many vertebrate classes including fish, amphibians and reptiles, but for the most part, research has been focused on non-reptilian hosts, amphibians in particular. More recently, reports of ranaviral infections of reptiles are increasing with over 12 families of reptiles currently susceptible to ranaviral infection. Reptiles are infected by ranaviruses that are genetically similar to, or the same as, the viruses that infect amphibians and fish; however, physiological and ecological differences result in differences in study designs. Although ranaviral disease in reptiles is often influenced by host species, viral strain and environmental differences, general trends in pathogenesis are emerging. More experimental studies using a variety of reptile species, life stages and routes of transmission are required to unravel the complexity of wild ranavirus transmission. Further, our understanding of the reptilian immune response to ranaviral infection is still lacking, although the considerable amount of work conducted in amphibians will serve as a useful guide for future studies in reptiles. 


\section{Ranaviruses and Reptiles}

2 Wytamma Wirth ${ }^{1}$, Lin Schwarzkopf ${ }^{2}$, Lee F Skerratt ${ }^{3}$, and Ellen Ariel ${ }^{1}$

$3{ }^{1}$ College of Public Health, Medical and Vet Sciences, James Cook University of North Queensland,

4 Townsville, QLD, Australia

52 College of Science and Engineering, James Cook University of North Queensland, Townsville, QLD,

6 Australia

$7{ }^{3}$ Melbourne Veterinary School, Faculty of Veterinary and Agricultural Sciences, University of Melbourne,

8 Melbourne, Australia

9 
10

11

12

13

14

15

16

17

18

19

20

21

22

23

24

25

26

27

28

29

30

31

32

33

34

35

36

37

38

39

40

41

42

43

44

45

46

47

48

49

50

51

52

53

54

55

56

57

58

\begin{abstract}
Ranaviruses can infect many vertebrate classes including fish, amphibians and reptiles, but for the most part, research has been focused on non-reptilian hosts, amphibians in particular. More recently, reports of ranaviral infections of reptiles are increasing with over 12 families of reptiles currently susceptible to ranaviral infection. Reptiles are infected by ranaviruses that are genetically similar to, or the same as, the viruses that infect amphibians and fish; however, physiological and ecological differences result in differences in study designs. Although ranaviral disease in reptiles is often influenced by host species, viral strain and environmental differences, general trends in pathogenesis are emerging. More experimental studies using a variety of reptile species, life stages and routes of transmission are required to unravel the complexity of wild ranavirus transmission. Further, our understanding of the reptilian immune response to ranaviral infection is still lacking, although the considerable amount of work conducted in amphibians will serve as a useful guide for future studies in reptiles.
\end{abstract}

\title{
Introduction
}

Ranaviruses (family Iridoviridae) are emerging lethal pathogens of ectothermic vertebrates. First discovered in 1965 (Granoff, Came \& Rafferty, 1965), ranaviruses were initially studied for their interesting molecular biology but rose to reportable pathogen status as more epizootics were discovered (Schloegel et al., 2010; Gray \& Chinchar, 2015). The vast majority of research on the genus Ranavirus has been conducted in amphibians (Rana is Latin for frog), but despite their name, ranaviruses do not occur only in amphibians (Chinchar \& Waltzek, 2014). This group of viruses infects over 175 species of ectothermic vertebrates; including reptile species from at least 12 different families (Duffus et al., 2015). Temperature appears to be the major factor preventing ranaviral infection outside of ectothermic vertebrates; these viruses can replicate in mammalian cell lines, but only when the temperature is below $32^{\circ} \mathrm{C}$ (Gray \& Chinchar, 2015).

Many advances in the field of ranavirology have been made since the discovery of ranaviruses; however, for the most part, this research is specific to amphibians. Reptiles and amphibians are very different physiologically and although they sometimes share habitats, their ecology is different. Some results from one host group can translate to the other; however, there is no substitute for host-specific research. As ranavirus research continues, it is important to focus efforts on all Classes of hosts, including reptiles.

Since the initial report of ranaviruses in reptiles in the early 1980s (Heldstab \& Bestetti, 1982), infections have been reported in wild and captive reptiles, and the number of reports continues to grow (Duffus et al., 2015). In this review, we summarise findings in all areas of reptilian ranavirus research. We identify major gaps in this field of knowledge and include recommendations for future research directions.

\section{Survey Methodology}

To ensure this review included as many publications focusing on ranaviruses and reptiles as possible, an extensive search of multiple databases using broad search queries was conducted. Databases used in the search strategy included: Web of Science, PubMed, and Google Scholar. The search strategy included keywords such as 'ranavirus' and 'reptiles' and their conjugations as well as more specific terms such as 'turtle', 'lizard', and 'snake'. To broaden the search further, references for articles found in the initial database search were then assessed for content relating to ranaviruses and reptiles. As a baseline for general ranavirus literature, relevant references were extracted from the 2015 Ranavirus book (Gray \& Chinchar, 2015). 
59

60

61

62

63

64

65

66

67

68

69

70

71

72

73

74

75

76

77

78

79

80

81

82

83

84

85

86

87

88

89

90

91

92

93

94

95

96

97

98

99

100

101

102

103

104

105

106

107

108

\section{Taxonomy}

Ranaviruses are large $(\sim 150 \mathrm{~nm})$, nucleocytoplasmic viruses with icosahedral virions and double-stranded DNA genomes that contain approximately 100 genes (Jancovich et al., 2015). Ranavirus is a genus in the family Iridoviridae: a group of five related viral genera. Of the five Iridoviridae genera, only ranaviruses cause significant disease in wild reptiles.

The taxonomy of the genus Ranavirus is changing; as more viruses are isolated and sequenced a clearer picture of the phylogenetic distribution of this group is developing. The international committee on taxonomy of viruses (ICTV) currently recognises eight species in the genus Ranavirus (Lefkowitz et al., 2018), none of which were originally isolated from reptiles. The official ICTV process of species recognition takes time and coordination within the scientific community. Many isolates, including isolates from reptiles, remain unclassified (Chinchar et al., 2017).

The current phylogeny of the genus Ranavirus can be subdivided into five major lineages based on comparison of conserved genes (Claytor et al., 2015; Jancovich, 2015; Stohr et al., 2015; Price et al., 2017). No Ranavirus lineage exclusively infects reptiles, and the majority of reptile infections appear to originate from putative amphibian specialist viruses (Price et al., 2017). The factors that control the host specificity of these viruses remain unknown. Phylogenetic analyses of sequences from different reptilian and amphibian viruses have revealed that viruses found in reptiles are often more closely related to amphibian ranaviruses from the same geographical region than to each other (Stohr et al., 2015). This provides support for the hypothesis that the jump into reptile hosts is relatively recent and has occurred multiple times (Jancovich et al., 2010, Stohr et al., 2015).

\section{Bibliometrics}

Despite a lack of host specificity, the vast majority of ranaviral literature is on amphibians. As of February 2018, 449 references were returned when the Web of Science ${ }^{\text {m }}$ database was queried for the topic 'ranavirus'. Of these, over 200 used the term 'amphibian' in their title or abstract while fewer than 60 used the term 'reptile'. However, plotting the usage of these terms over the last 10 years shows a steady increase in the ratio of 'reptile' to 'amphibian' terms, possibly reflecting an increase in reptilian ranavirus research or an increased awareness of the role of reptiles in this disease (Figure 1).

\section{Diagnostics and surveillance}

The World Organization for Animal Health (OIE) provides guidelines for diagnostic methods in their Diagnostic Manual for Aquatic Animal Health (OIE, 2012), and Miller et al. (2015) summarised the diagnostic techniques used in ranaviral research. The most commonly used methods to confirm the presence of a ranavirus in host samples have included electron microscopy, enzyme-linked immunosorbent assays (ELISAs), viral isolation, immunohistochemistry (IHC), DNA amplification using polymerase chain reaction (PCR), and more recently, next generation sequencing. All of these techniques have been used at some stage in the study of ranaviruses from reptiles; however, the selection of diagnostic technique is highly dependent on the resident expertise in the laboratory, the data required, and the type of study (Miller et al., 2015). Before their application in new hosts or against new pathogens, all diagnostic techniques should be thoroughly tested and optimised with appropriate controls (e.g. different species of reptiles or ranaviruses, or both) (Wobeser, 2007).

Most ranaviruses can be grown using commercially available fish cell lines (Miller et al., 2015). Reptile cell lines such as Russell's viper heart cells, gecko lung cells, turtle heart, and iguana 
109 heart cells have also been used successfully to isolate ranaviruses from reptiles (Hyatt et al.,

110

111

112

113

114

115

116

117

118

119

120

121

122

123

124

125

126

127

128

129

130

131

132

133

134

135

136

137

138

139

140

141

142

143

144

145

146

147

148

149

150

151

152

153

154

155

156

157

2002, Johnson et al., 2008, Alves de Matos et al., 2011).

Serological surveys, employing various ELISAs, have been used to assess reptiles for antiranaviral antibodies (Johnson et al., 2010; Ariel et al., 2017). Although these ELISA-based surveys have successfully detected anti-ranaviral antibodies in wild and captive chelonians and experimentally infected reptiles, the utility of such surveys is not clear due to the inconsistency of sero-conversion after ranaviral infection in reptiles. A captive group of chelonians, with a history of iridovirus outbreak, had a low proportion of seropositive individuals, and wild populations of North American chelonians were shown to have low sero-prevalence (Johnson et al., 2010). Experimentally-infected Australian reptiles do not show consistent patterns of seroconversion, although wild populations can have high levels of antibodies (Ariel et al., 2017). Sero-surveys of large aquatic reptiles, such as freshwater turtles, could be useful as an indication of ranavirus occurring in freshwater environments but they would likely underestimate the true prevalence of exposure unless the accuracy of the test is determined (Ariel et al., 2017, Johnson et al., 2010). This is because exposed animals may fail to sero-convert or die before they are surveyed. Reptile antibody titres vary seasonally (more antibodies are produced in the warmer months), which must be taken into account when determining sensitivity and specificity cut-off values for diagnostic tests (Wobeser, 2007; Zimmerman et al., 2010; Meddings, 2011). Seasonal variation of anti-ranaviral antibodies has not been assessed. Using total lgY levels as an internal control may minimise diagnostic errors resulting from seasonal variations in antibody levels.

PCR based assays have been used conventionally and in quantitative real-time assays to detect reptilian ranaviruses in a number of sample types including blood, oral and cloacal swabs, and fresh and fixed tissues (Pallister et al., 2007; Allender et al., 2013a; Goodman et al., 2013, Butkus et al., 2017; Leung et al., 2017; Maclaine et al., 2018). Molecular surveys of turtle populations for ranavirus have revealed that swabs and blood samples are not equally valid targets for ranavirus detection (Allender et al., 2013a). Goodman et al. (2013) also found that oral cloacal swabs were not as effective for ranavirus detection when compared with tail clip tissue samples. Given possible differences in sample type sensitivity, it would seem advisable to collect multiple samples (e.g. both blood and swabs) when conducting a molecular survey for reptilian ranaviruses (a method employed in many studies). It is also possible to use bone marrow as a source of DNA for ranavirus detection from reptile carcases in which other viable tissue samples may have decayed (Butkus et al., 2017).

The preferred target of ranaviral PCR assays is the major capsid protein (MCP) gene as it is highly conserved throughout the ranaviral lineage (Miller et al., 2015). Because of the multispecies host range of most reptile ranaviruses, reptile-specific PCR assays are not required. Many different PCR assays have been used in reptile studies; generally the assay of choice depends on the question asked. PCR assays with broad targets such as those from Mao et al. (1997) have been used in surveys (Goodman et al., 2013) and more specific, probe-based PCR assays have also been used in surveys of reptiles. Probe-based assays generally sacrifice broad detection range for increased sensitivity (Allender et al., 2013a). Sensitive probe-based assays have also been used in experimental infections with a known viral target to determine levels of infection (Allender et al., 2013c). A new qPCR assay developed by Leung et al. (2017) should provide more accurate viral load determination by using an internal host control DNA target conserved in reptiles. Large product PCR assays have been used in phylogenetic studies of reptilian ranaviruses (Stöhr et al., 2015). As the cost of sequencing decreases, it is becoming 
158

159

160

161

162

163

164

165

166

167

168

169

170

171

172

173

174

175

176

177

178

179

180

181

182

183

184

185

186

187

188

189

190

191

192

193

194

195

196

197

198

199

200

201

202

203

204

205

206

207

increasingly popular to use high throughput sequencing methods to more accurately identify and characterise viral isolates (Hick et al., 2016; Subramaniam et al., 2016).

Environmental DNA (eDNA) -based detection may be an effective method for assessing the presence of ranaviral DNA in populations of aquatic reptiles. Ranavirus outbreaks in aquatic frog populations have been detected using eDNA PCR methods (Hall et al., 2016). Aquatic reptiles (Testudines) with ranaviral infections can shed virions into their surroundings, indicating that eDNA detection may be possible, although no publication has yet confirmed this in situ (Brenes et al., 2014). Mosquitoes may be useful targets for detecting ranaviruses in reptile populations. Kimble et al. (2014) found ranaviral DNA in mosquitoes associated with a box turtle epizootic. Ranaviral PCR testing of mosquitoes (xenosurveillance) could be combined with DNA barcoding to determine the origin of the mosquito blood meal as well as the presence of ranavirus (Bitome-Essono et al., 2017).

Immunohistochemistry $(\mathrm{IHC})$ and other in situ labelling methods have been successfully used in reptilian ranaviral studies to visualise the location of the viral protein in tissue samples (Hyatt et al., 1991; Ariel et al., 2015). Unlike PCR, IHC assays sample for target proteins and locate them in histological sections of tissues. Ranaviral IHC assay results combined with histopathology can be used to correlate pathology with the location of viral antigens (Becker et al. 2013; Ariel et al., 2015; Forzán et al., 2015). Ariel et al. (2015) used cross-reactive polyclonal anti-EHNV antibodies to detect BIV antigens in infected turtle tissues. They found IHC staining associated with vascular endothelial cells, possibly indicating that viraemia preceded the systemic infection observed in these animals.

Another antigen assay has used anti-ranaviral monoclonal antibodies in a double antibody sandwich ELISA to detect viral particles in soft-shelled turtles (Zhang et al., 2010). In this case, the virion was detected with $98 \%$ specificity when compared with conventional PCR as the gold standard.

Because of the variability in ranaviral disease signs and severity within and among reptile species (see pathology section), suspected cases of ranaviral disease must be confirmed with laboratory diagnostic techniques. Epidemiological surveys must be adequately designed and powered to ensure ranavirus prevalence is accurately reported (Gray et al., 2015). There have been several studies reporting the negative results of epidemiological surveys (Hanlon et al., 2016; Kolesnik et al., 2017; Winzeler et al., 2018). These results are extremely valuable as they also help describe the distribution and emergence patterns of reptilian ranaviruses; however, it is important to consider the sampling protocols and diagnostic choice when evaluating and comparing epidemiological studies (Gray et al., 2015).

\section{Distribution, host range and impact}

Ranaviruses capable of infecting reptiles have been found on all continents, except Antarctica (Duffus et al., 2015). Ranaviruses have been detected in over 12 families of the orders Testudines (turtles, tortoises and terrapins) and Squamata (lizards and snakes). It is important to note that given reptile populations often share habitat with susceptible fish and amphibian species, it may be possible to infer reptile ranavirus distributions based on amphibian ranaviral prevalence patterns and vice versa (Duffus et al., 2015). It is not clear if reptilian ecology influences patterns of ranavirus host range or susceptibility. Aquatic reptiles may be more likely to be exposed to ranaviruses; however, ranaviruses are still detected in terrestrial reptiles (Duffus et al., 2015). There is some evidence aquatic turtles are less susceptible to ranaviral disease; however, this is far from settled and should be investigated further (Brunner et al., 
208

209

210

211

212

213

214

215

216

217

218

219

220

221

222

223

224

225

226

227

228

229

230

231

232

233

234

235

236

237

238

239

240

241

242

243

244

245

246

247

248

249

250

251

252

253

254

255

256

257

2015). Recently, Adamovicz et al. (2018) reported that the use of moist microhabitats is correlated with ranavirus detection in eastern box turtles.

\section{- Testudines (turtles, tortoises and terrapins)}

Koch's postulates have been confirmed in Testudines with infection and disease demonstrated in red-eared sliders (Trachemys scripta elegans) and box turtles (Terrapene ornata ornata) infected with a Burmese star tortoise Ranavirus isolate (Johnson et al., 2007). The first reported cases of ranaviral infections in Testudines were identified microscopically during the 1980s in Hermann's tortoises (Testudo hermanni) in Switzerland (Heldstab \& Bestetti, 1982). Following this, ranaviruses were predominantly isolated from box turtles (Terrapene carolina) and were identified as the aetiological agent of 'red neck disease' in the soft-shelled turtle (Pelodiscus sinensis) (Chen et al., 1999). In the last decade, several new reports of ranaviral infections in Testudines have been published (Johnson et al., 2008; Johnson et al., 2010; Belzer \& Seibert, 2011; Allender, 2012; Stohr et al., 2015; Perpiñán et al., 2016; Butkus et al., 2017, Agha et al., 2017; Archer et al., 2017; Adamovicz et al., 2018). Despite the increasing number of reports of infections in the Testudines, ranaviral disease in these reptiles is still likely to be underreported due to a lack of awareness, an incomplete understanding of the pathology caused by the disease, few long-term studies, and minimal population monitoring (Duffus et al., 2015). Sea turtles are a group of reptiles that have received little attention from ranavirus researchers, despite the existence of ranavirus infections in marine fish (Whittington et al. 2010).

\section{- Squamata (lizards and snakes)}

The first reports of ranaviral infection in squamates came after several green tree pythons were seized during an attempt to illegally import them into Australia from Indonesia. Hyatt et al. (2002) reported that these snakes were infected with an FV3-like ranavirus isolate. In 2005, Marschang et al. (2005) reported the first ranaviral infection in lizards. The reports of ranavirus infections in squamates have been, for the most part, restricted to groups of captive lizards, providing little evidence of the role of ranavirus infection in wild squamate populations (Stohr et al., 2013; Behncke et al., 2013; Stohr et al., 2015; Tamukai et al. 2016). Although no epizootics have been reported, ranaviral DNA and seropositive animals have been detected in wild squamate populations (Alves de Matos et al., 2011, Ariel et al., 2017; Goodman et al., 2018).

\section{- Rhynchocephalia (tuatara), Archosaurs (crocodiles, birds)}

There have been no documented cases of ranavirus infections in animals from the other groups of the class Reptilia, namely the Rhynchocephalia (tuatara) and the archosaurs (crocodilians and birds). The tuatara only inhabit parts of New Zealand, and although ranaviruses are believed to be present (i.e. short-finned eel ranavirus, Bovo et al., 1999), no studies have been published on the presence of ranavirus in tuatara. While yearling Australian freshwater crocodiles (Crocodylus johnstoni) were exposed to ranavirus (BIV) under laboratory conditions, this challenge did not cause any adverse effects in the yearlings and the virus could not be reisolated (Ariel et al., 2015). A serosurvey of wild freshwater crocodiles did show evidence of anti-ranaviral antibodies, indicating that wild populations are likely exposed (Ariel et al., 2017). It is important to continue to study apparently resistant species, like crocodiles, as they may give insights into the determinants of immunity. Birds and reptiles are closely related; crocodiles are genetically more closely related to birds than they are to lizards. There are no reports of birds infected by ranaviruses (this is probably related to endothermy); despite this, birds may still play a role in ranaviral transmission. It has been hypothesised that migratory birds, acting as mechanical vectors, are responsible for some of the geographic transmission of ranaviruses (Whittington et al., 1996). 


\section{Pathology}

259 The clinical signs and pathogenesis of natural ranaviral infection in reptiles can be extremely variable. Mortality during an epizootic can range from $0-100 \%$ and the effect on a host can vary from quite mild to extremely severe, requiring immediate veterinary attention or euthanasia (Miller et al., 2015). There is evidence that reptiles can also be asymptomatic carriers of ranaviruses (Stohr et al., 2013, Goodman et al., 2018). Quiescent viral reactivation in amphibians that have recovered from infection is possible; however, the same is not known for reptiles (Robert et al., 2014). The complex presentation and inconsistency in the pathogenesis of ranaviral infection in reptiles may occur because of the influence of host physiology and life history, and varying degrees of viral virulence, stressors, and temperatures acting on the course and outcome of infection (see Susceptibility section).

Descriptions of pathogenesis in reptiles infected with a variety of ranaviral strains in several host species under experimental, wild, and captive conditions are presented in Table 1. Despite differences in descriptions of pathogenesis and the fact the reports are often confounded with co-infections (Sim et al., 2016, Adamovicz et al., 2018), some common patterns of ranaviral pathology have emerged.

General lethargy and inappetence are associated with many cases of ranaviral infection in reptiles; however, such clinical signs are common to many diseases and are not pathognomonic for ranaviral infection. Turtles often present with respiratory signs, including nasal and oral discharge (Johnson et al., 2007; Johnson et al., 2009; Allender et al., 2013b; Kimble et al., 2017). Oedema, especially of the eyes or neck, is also commonly associated with this infection in the order Testudines (Chen et al., 1999; Johnson et al., 2007; Johnson et al., 2008; Johnson et al., 2009; Allender et al., 2013b). The clinical signs of ranaviral infection in Squamates are scarcely described. This is partially due to the lack of experimental infection trials in this group, which would help describe pathogenesis markers. Maclaine et al. (2018) recently demonstrated the susceptibility of an Australian lizard species (Intellagama lesueurii lesueurii) to ranaviral infection, documenting that clinical signs and histopathological changes varied with inoculation route. With increasing descriptions of ranaviral infected lizards over the last decade, an emerging trend suggests that skin lesions may be a common occurrence (Behncke et al., 2013; Stohr et al., 2013; Tamukai et al., 2016).

Ranaviral infections are systemic, and there is often extensive damage to multiple organs during infection, especially the liver and spleen in reptiles. Liver lesions are also very common in the pathogenesis of ranaviruses in amphibian and fish species (Miller et al., 2015). Histopathology is frequently characterised by inflammation and multifocal necrosis in multiple organs, and is often associated with hematopoietic tissue (Ariel et al., 2015). Reptilian hosts of ranaviruses experience a range of histological changes including necrosis and inflammation of the respiratory tract, pneumonia, conjunctivitis, stomatitis, esophagitis, tracheitis, necrosis of endothelial cells and the submucosa of the gastrointestinal tract, glomerulonephritis, multifocal hepatic necrosis, splenitis, intracytoplasmic inclusion bodies in many tissues, and necrotizing myositis (see Table 1). Evidence from epizootics in reptiles indicates that ranaviral infection can be accompanied by secondary pathogens that may exacerbate the disease and mask clinical signs of ranaviral infection (Stohr et al., 2013; Sim et al., 2016; Archer et al., 2017).

\section{Transmission}

The natural route of transmission of ranaviruses in wild populations of reptiles is still debated, although experimental data suggest multiple transmission routes are possible (Brunner et al., 2015). During an experimental challenge of adult red-eared sliders (Trachemys scripta elegans), 
308

309

310

311

312

313

314

315

316

317

318

319

320

321

322

323

324

325

326

327

328

329

330

331

332

333

334

335

336

337

338

339

340

341

342

343

344

345

346

347

348

349

350

351

352

353

354

355

356

357
Johnson et al. (2007) found that the orally exposed animals were refractory to infection while animals challenged with the same dose via intramuscular injection developed severe disease. In another study, exposure to ranavirus in water via cohabitation resulted in infection in red-eared slider hatchlings ( $T$. scripta elegans), although the route of infection was not determined, and the concentration of virus in the water was not quantified (Brenes et al., 2014). Ariel et al. (2015) found that adult freshwater turtles (Emydura krefftii and Elseya latisternum), freshwater crocodiles (C. johnstoni), and several species of snakes were refractory to infection irrespective of the route of exposure. The hatchlings of both species of freshwater turtles were susceptible to infection via intra-coelomic exposure although oral inculcation was not attempted. Juvenile Australian eastern water dragons (Intellagama lesueurii lesueurii) developed ranaviral disease from all exposure routes tested (oral, intramuscular, and cohabitation) (Maclaine et al., 2018).

Differences in susceptibility via different routes of exposure may reflect real differences in natural transmission routes between reptiles and other Classes. More experimental studies using a variety of species, life stages, and routes of transmission are needed to resolve this.

Amphibians are highly susceptible to ranaviral infection via all tested forms of inoculation (water bath, skin contact, oral inoculation or injection) (Miller et al 2015). Fish are also susceptible via multiple inoculation routes, although it appears to be species-dependent (Jensen et al., 2009; Gobbo et al., 2010; Jensen et al., 2011). Differences in viable transmission routes result in different epidemiologies, and thus research from other host classes with different viable transmission routes may not accurately reflect risks and susceptibility of reptilian populations. It is therefore important to account for variation in transmission routes among reptile species when developing statistical models for reptilian disease.

\section{Vectors}

Humans are contributing to the global spread of ranaviruses, primarily though global animal trade (Kolby et al., 2014; Duffus et al., 2015; Stöhr et al., 2015). Although there are reports of ranaviral infection in traded reptiles (Hyatt et al, 2002; Stohr et al., 2013), no systematic survey of ranaviral infection in traded reptiles has been conducted. There have been some ranaviral disease outbreaks in private reptile collections and zoos (Marschang et al., 2005; Sim et al., 2016), but the full extent of disease prevalence is hard to assess, both because of inapparent infections, and lack of reporting of dead animals amongst reptile breeders and collectors.

Ranaviral DNA sequences have been identified in mosquitoes associated with a ranavirus outbreak in box turtles, providing evidence for vector transmission (Kimble et al., 2014). Ranaviral DNA and antigens have been detected in blood and blood-associated tissues of reptiles (Allender et al., 2013a, Ariel et al., 2015, Miller et al., 2015). Leeches are common ectoparasites of aquatic reptile species and can act as vectors for blood-borne diseases (Siddall \& Desser, 1992; Watermolen, 1996; Readel et al., 2008). There has been at least one report of a ranavirus-positive leech (PCR for MCP) associated with an infected amphibian host, although there are no reports for leeches of reptiles (Hardman et al., 2013). Some low density reptile populations that experience ranaviral epizootics do not appear to be capable of propagating ranaviral disease through physical contact alone (Brunner et al., 2015). Despite these indicators of the possible involvement of vectors in ranavirus transmission, no experimental studies have been published that support or refute this hypothesis in reptiles.

\section{Reservoirs}

Ranaviral virions are extremely stable in controlled settings, they are capable of withstanding high and low $\mathrm{pH}$ and temperatures and are resistant to desiccation, remaining viable for days to 
358

359

360

361

362

363

364

365

366

367

368

369

370

371

372

373

374

375

376

377

378

379

380

381

382

383

384

385

386

387

388

389

390

391

392

393

394

395

396

397

398

399

400

401

402

403

404

405

406

407

years (Granoff et al., 1965; Langdon et al. 1986, Langdon, 1989; Munro et al., 2016; Nazir et al., 2012). These qualities of stability may not to carry to ecological settings as interactions with the aquatic biotic communities can reduce the longevity of infectious ranaviral particles (Brunner et al., 2015). Reinauer et al., (2005), found that tortoise ranaviruses remain infectious in lake water samples and in soil for many days; however, biotic communities were not quantified. It also appears that moisture is important for persistence in soil environments (Brunner et al., 2015, Nazir et al., 2012). Animals, both live and dead, are also probably reservoirs for reptilian ranavirus infections. Reptiles are known to consume frogs, fish, and even other reptiles as a part of their natural diet (Kischinovsky et al., 2017). Dead and decaying animals continue to release virions and might be consumed by susceptible reptiles (Brunner et al., 2015; Gray et al., 2015). Asymptomatic amphibians are sometimes reservoirs; they can spread virus to other susceptible species, and possibly reptiles, in multispecies ranavirus epizootics (Brenes et al., 2014; Brunner et al., 2015; Miller et al., 2011).

\section{Correlates of susceptibility}

Reptiles are ectotherms and so their physiology is strongly influenced by the temperature of their surrounding environment. By extension, the innate and adaptive immune response of reptiles is also linked to available environmental temperatures (Zimmerman et al., 2010). Ranavirus-infected reptiles, such as turtles, exhibit temperature-dependent pathogenesis (Allender et al., 2013b, Allender et al., 2018) similar to that observed in fish and amphibians (Brunner et al., 2015; Brand et al., 2016); however, the replication efficacy of the virus is also linked to temperature (Ariel et al., 2009). Thus, it is difficult to determine the degree to which temperature-dependent pathogenesis is a result of the effect of temperature on the replication of the virus or on the immune system of the turtles. Several studies have quantified the temperature-dependent activity of the innate immune system of reptiles (Merchant et al., 2006; Ferronato et al., 2009; Merchant et al., 2012). In experimental infections of ranaviruses, temperature is often uncontrolled (reported as 'room temperature').

Allender et al. (2013) suggested that an environmental temperature change of $6^{\circ} \mathrm{C}$ is enough to significantly reduce ranavirus loads and halve morbidity in infected adult turtles. However, in a follow up study, in juvenile turtles, they found that increased temperature reduced median survival time of all four species tested (Allender et al., 2018). Similar patterns of reduced time until death but lower mortality rates with increasing temperature have been seen with other environmental temperature-dependent host-pathogen systems such as amphibians with chytridiomycosis (Berger et al., 2004). This pattern of temperature-related susceptibility in reptiles is important for future studies to quantify.

The effects of stressors on reptilian ranaviral disease are poorly understood (Polakiewicz et al., 2013). Several studies in amphibians have examined the effects of stressors on disease in experimental infections (Echaubard et al., 2010; Forson and Storfer, 2006; Haislip et al., 2012; Kerby et al., 2011; Reeve et al., 2013), and epidemiological studies have looked for correlations between environmental stressors and ranaviral prevalence (St-Amour et al., 2008; Brunner et al., 2015). The immunosuppressive effects of some anthropogenic stressors (e.g. pesticides, herbicides, and heavy metals) on the reptile immune system suggest a possible mechanism of environmental influence on susceptibility. Future epidemiological studies should consider these factors (Keller et al., 2006; Soltanian, 2016).

\section{Immunology}

Studies of ranaviral host immunity and immune evasion in amphibians are extensive, while similar work in reptiles is limited (Grayfer et al., 2015). The immunology section in the 2015 Ranavirus book, although comprehensive on amphibians, only mentions reptiles in passing 
408 (Grayfer et al., 2015). Immunology is an area in which a great number of unknowns remain for 409 ranaviruses and reptiles.

410

411

412

413

414

415

416

417

418

419

420

421

422

423

424

425

426

427

428

429

430

431

432

433

434

435

436

437

438

439

440

441

442

443

444

445

446

447

448

449

450

451

452

453

454

455

456

\section{Immunology - Innate}

Antimicrobial peptides (AMPs) are likely involved in amphibian ranaviral defence. Amphibian antimicrobials such as E2P and R2P are cable of inactivating ranaviral virions through direct interaction at all temperatures tested $\left(0-26^{\circ} \mathrm{C}\right)$ (Chinchar et al., 2001). Reptile species also possess a range of antimicrobial peptides, primarily cathelicidins and $\beta$-defensins (Preecharram et al., 2010; van Hoek, 2014; Ageitos et al., 2017). Homologs of the anti-ranaviral peptides in amphibians (class-four AMPs) have not been found in reptiles, although defensin-like peptides from the albumin of marine turtles possessed antiviral activity against enveloped rhabdoviruses (Chattopadhyay, 2006). No reptilian AMPs have, however, been specifically assayed for antiranaviral activity.

Few studies have looked at the role of cytokines against ranaviruses in reptile immunity and these should be investigated in future studies. One study found that IFN- $\gamma$ appears to have some antiviral activity in ranavirus infected soft-shelled turtle cells, although the mechanisms are unclear (Fu et al., 2014).

The reptile serum complement system also deserves further consideration, as it is capable of inhibiting viral replication (Merchant et al., 2005). Serum from American alligators (Alligator mississippiensis) exhibits antiviral activity against human immunodeficiency virus type-1, which has been attributed to action of the complement system (Merchant et al., 2005). The effect of the reptilian complement system on ranaviral replication efficiency has not been investigated.

Extensive work has attempted to elucidate the complex role of amphibian macrophages in ranaviral infection, although work in reptile hosts is limited (Grayfer et al., 2015). It has been hypothesized that ranaviral infection is partly dependent on the phagocytic and endocytic activity of macrophages. Ranaviruses overcome the antiviral defences of macrophages and use the cells for persistence and dissemination throughout the host. Ectothermic vertebrates, including reptiles, possess a unique type of phagocytic B cell capable of ingesting foreign particles (Zimmerman et al., 2009). It is conceivable that these phagocytic B cells may also be involved in ranavirus dissemination.

\section{Immunology - adaptive}

Much less is known about the reptilian adaptive response than the innate response system (Rios \& Zimmerman, 2015). Studies of the role of the adaptive immune system in clearing ranaviral infection have been almost exclusively restricted to amphibians and fish (Chen \& Robert, 2011; Grayfer et al., 2015). The only studies of ranaviruses and the adaptive arm of the reptilian immune system have been through epidemiological studies. Anti-ranaviral $\lg Y$ is produced as a long-lasting and specific adaptive response to infection and is the preferred target of reptilian serological assays (Johnson et al., 2010; Zimmerman et al., 2010; Ariel et al., 2017). The virus neutralising ability of anti-ranaviral antibodies detected in reptile populations has not been determined. Studies of $T$ cell proliferation in response to ranaviral infection have not been conducted in reptiles and it is not clear if reptiles develop long-lasting immunological memory against ranaviral infection. Amphibian researchers have made a start on these questions, providing useful guidance for future studies in reptiles (Grayfer et al., 2015).

\section{Treatment}


457 For treatment of acute ranaviral infection, several antivirals have been considered and tested

458 (Allender, 2012; Li et al., 2015; Sim et al., 2016). However, there are few examples of their 459 successful use to treat clinical cases (Johnson et al., 2010; Allender, 2012; Miller et al., 2015). 460 Many in vitro antiviral studies that show promising results do not carry to in vivo models or have 461 not been thoroughly tested in vivo.

462

Acyclovir, the most extensively studied antiviral in reptiles, does not appear to be an effective anti-ranaviral agent. Viral thymidine kinase (present in some herpesviruses and ranaviruses) is required for activation of acyclovir, which then blocks viral DNA replication through competitive inhibition of the viral DNA polymerase (Beutner, 1995). In vitro results have been mixed; Johnson (2006) found that acyclovir provided a dose-dependent partial inhibition of a FV3-like ranavirus, while Ferguson et al. (2014) found no statistically significant effect of acyclovir on FV3 replication. Plasma concentrations of orally dosed acyclovir do not reach levels in turtles that have been suggested as sufficient for ranavirus inhibition (Allender, 2012, Gaio, 2007). It is difficult to interpret the results of the use of this drug in uncontrolled clinical settings; however, it is clear that in several cases acyclovir has not stopped the progression of reptilian ranaviral disease (DeVoe et al., 2004, Johnson et al., 2008).

Pharmacological studies of the effectiveness of different antivirals at different severities and durations of ranaviral infection in reptiles have not been conducted, but would be extremely useful for guiding the treatment of acute ranaviral infection in reptiles.

Iridoviral vaccine development has been limited to the aquaculture industry (Miller et al., 2015). Frogs can produce long-lasting FV3-specific neutralising antibodies on second exposure (Maniero et al. 2006), suggesting it would be possible to develop vaccines for them. Reptiles can produce anti-ranaviral antibodies during infection (Ariel et al., 2017; Johnson et al., 2010), and vaccines have been developed for other reptilian pathogens with varying success (Horner et al., 1988; Jacobson et al., 1991; Mohan et al., 1997; Marschang et al., 2001; Yang et al., 2007). Vaccine research and development are extremely costly, and more epidemiological research is required to determine if the development of a ranaviral vaccine would be efficacious for wild reptilian populations. However, there are several instances where a vaccine could be useful for small scale use. For example: in zoo collections, for valuable broodstock, and for endangered or at risk populations. Epidemiological studies may feasibly identify and prophylactically treat animals most at risk.

Environmental temperature can have a substantial effect on the humoral immune system (e.g. antibody production) of ectotherms (Widal, 1897), which opens up the possibility of influencing the outcome of an infection via control of environmental temperatures (see Susceptibility section). Increased ambient temperature has been suggested as a treatment method for ranavirus infection in reptiles (Hyndman \& Marschang, 2017). However, Allender et al. (2018) recently reported that increased temperature $\left(22^{\circ} \mathrm{C}\right.$ to $\left.27^{\circ} \mathrm{C}\right)$ resulted in reduced median survival time of ranaviral infected Testudines. It is likely that there is a threshold temperature, which dramatically improves survival as occurs with chytridiomycosis in amphibians (Berger et al 2009). Further investigation is required to determine the optimal temperature for increasing survival of ranaviral infected reptiles, which may also be viral and host species dependent.

\section{Future research and conclusions}

The field of ranavirus research is dominated by studies on fish and amphibians, these studies can serve as a guide for the tremendous number of directions ranaviral research in reptiles could take. An increase in the number of epidemiological studies and surveys of ranaviruses in 
507 reptile populations is required to understand the distribution of these viruses in the class

508 Reptilia, and to identify at-risk populations. Pathogenesis and transmission of ranaviruses in

509 reptiles are still poorly understood and will require elucidation before this disease can be

510 correctly modelled and appropriately managed in reptile populations. Reptile ranaviral host

511 immunity and immune evasion strategies of the virus are also under-represented in the

512 literature. From predator to pollinator to prey, reptiles play vital roles in the ecosystems they

513 inhabit, but like amphibians, reptiles are experiencing global declines (Gibbons et al., 2000). It

514 is, therefore, imperative that research continues to expand our understanding of reptiles and

515 ranaviruses to help protect this valuable part of biodiversity. 


\section{References}

518

519

520

521

522

523

524

525

526

527

528

529

530

531

532

533

534

535

536

537

538

539

540

541

542

543

544

545

546

547

548

549

550

551

552

553

554

555

556

557

558

559

560

561

562

563

564

565

566
Adamovicz L., Allender MC., Archer G., Rzadkowska M., Boers K., Phillips C., Driskell E., Kinsel MJ., Chu C. 2018. Investigation of multiple mortality events in eastern box turtles (Terrapene carolina carolina). PloS one 13:1-20.

Ageitos JM., Sánchez-Pérez A., Calo-Mata P., Villa TG. 2017. Antimicrobial peptides (AMPs): Ancient compounds that represent novel weapons in the fight against bacteria. Biochemical Pharmacology 133:117-138. DOI: https://doi.org/10.1016/j.bcp.2016.09.018.

Agha M., Price SJ., Nowakowski AJ., Augustine B., Todd BD. 2017. Mass mortality of eastern box turtles with upper respiratory disease following atypical cold weather. Diseases of Aquatic Organisms 124:91-100. DOI: 10.3354/dao03122.

Allender MC. 2012. Characterizing the epidemiology of ranavirus in north american chelonians: diagnosis, surveillance, pathogenesis, and treatment. University of Illinois at UrbanaChampaign.

Allender MC., Fry MM., Irizarry AR., Craig L., Johnson AJ., Jones M. 2006. Intracytoplasmic inclusions in circulating leukocytes from an eastern box turtle (Terrapene carolina carolina) with iridoviral infection. J Wildl Dis 42:677-684. DOI: 10.7589/0090-3558-42.3.677.

Allender MC., Mitchell MA., Mcruer D., Christian S., Byrd J. 2013. Prevalence, clinical Signs, and natural History Characteristics of frog virus 3-like infections in eastern Box turtles (Terrapene carolina carolina). Herpetological Conservation and Biology 8.2:308-320.

Allender MC., Mitchell MA., Torres T., Sekowska J., Driskell EA. 2013. Pathogenicity of Frog Virus 3-like Virus in Red-eared Slider Turtles (Trachemys scripta elegans) at Two Environmental Temperatures. Journal of Comparative Pathology 149:356-367. DOI: http://dx.doi.org/10.1016/j.jcpa.2013.01.007.

Allender MC., Bunick D., Mitchell MA. 2013. Development and validation of TaqMan quantitative PCR for detection of frog virus 3-like virus in eastern box turtles (Terrapene carolina carolina). Journal of Virological Methods 188:121-125. DOI: http://dx.doi.org/10.1016/j.jviromet.2012.12.012.

Allender MC., Barthel AC., Rayl JM., Terio KA. 2018. Experimental Transmission of Frog Virus 3-Like Ranavirus in Juvenile Chelonians at Two Temperatures. Journal of Wildlife Diseases:2017-07-181. DOI: 10.7589/2017-07-181.

Alves de Matos AP., da Silva Trabucho Caeiro MFA., Papp T., da Cunha Almeida Matos BA., Correia ACL., Marschang RE. 2011. New Viruses from Lacerta monticola (Serra da Estrela, Portugal): Further Evidence for a New Group of Nucleo-Cytoplasmic Large Deoxyriboviruses. Microscopy and Microanalysis 17:101-108. DOI: DOI: 10.1017/S143192761009433X.

Archer GA., Phillips CA., Adamovicz L., Band M., Byrd J., Allender MC. 2017. Detection of copathogens in free-ranging eastern box turtles (Terrapene carolina carolina) in illinois and tennessee. Journal of Zoo and Wildlife Medicine 48:1127-1134. DOI: 10.1638/20170148R.1.

Ariel E., Wirth W., Burgess G., Scott J., Owens L. 2015. Pathogenicity In Six Australian Reptile Species Following Experimental Inoculation With Bohle Iridovirus. Diseases of Aquatic Organisms.

Ariel E., Elliott E., Meddings JI., Miller J., Santos MB., Owens L. 2017. Serological survey of Australian native reptiles for exposure to ranavirus. Diseases of Aquatic Organisms 126:173-183. DOI: 10.3354/dao03172.

Ariel E., Nicolajsen N., Christophersen M-B., Holopainen R., Tapiovaara H., Bang Jensen B. 2009. Propagation and isolation of ranaviruses in cell culture. Aquaculture 294:159-164.

Bang Jensen B., Ersbøll A., Ariel E. 2009. Susceptibility of pike Esox lucius to a panel of Ranavirus isolates. Diseases of Aquatic Organisms 83:169-179. DOI: 10.3354/dao02021. 
567

568

569

570

571

572

573

574

575

576

577

578

579

580

581

582

583

584

585

586

587

588

589

590

591

592

593

594

595

596

597

598

599

600

601

602

603

604

605

606

607

608

609

610

611

612

613

614

615

616

Becker JA., Tweedie A., Gilligan D., Asmus M., Whittington RJ. 2013. Experimental infection of Australian freshwater fish with epizootic haematopoietic necrosis virus (EHNV). J Aquat Anim Health 25:66-76. DOI: 10.1080/08997659.2012.747451.

Behncke H., Stöhr a C., Heckers KO., Ball I., Marschang RE. 2013. Mass-mortality in green striped tree dragons (Japalura splendida) associated with multiple viral infections. The Veterinary record 173:248. DOI: 10.1136/vr.101545.

Belzer WR., Seibert S. 2011. A Natural History of Ranavirus in an Eastern Box Turtle Population. Turtle \& Tortoise Newsletter.18.

Benetka V., Grabensteiner E., Gumpenberger M., Neubauer C. 2007. First report of an iridovirus (Genus Ranavirus) infection in a Leopard tortoise (Geochelone pardalis pardalis). Wien Tierarztl Monatsschr:243-248.

Berger L., Longcore JE., Speare R., Hyatt A., Skerratt LF. 2009. Fungal diseases in amphibians. Amphibian biology 8:2986-3052.

Berger L., Speare R., Hines HB., Marantelli G., Hyatt AD., McDonald KR., Skerratt LF., Olsen V., Clarke JM., Gillespie G., Mahony M., Sheppard N., Williams C., Tyler MJ. 2004. Effect of season and temperature on mortality in amphibians due to chytridiomycosis. Australian veterinary journal 82:434-439.

Beutner KR. 1995. Valacyclovir: a review of its antiviral activity, pharmacokinetic properties, and clinical efficacy. Antiviral research 28:281-290.

Bitome-Essono P-Y., Ollomo B., Arnathau C., Durand P., Mokoudoum ND., Yacka-Mouele L., Okouga A-P., Boundenga L., Mve-Ondo B., Obame-Nkoghe J., Mbehang-Nguema P., Njiokou F., Makanga B., Wattier R., Ayala D., Ayala FJ., Renaud F., Rougeron V., Bretagnolle F., Prugnolle F., Paupy C. 2017. Tracking zoonotic pathogens using bloodsucking flies as "flying syringes." eLife 6:1-21. DOI: 10.7554/eLife.22069.

Blahak, S., \& Uhlenbrok C. 2010. Ranavirus infections in European terrestrial tortoises in Germany. In: Proceedings of the 1st International Conference on Reptile and Amphibian Medicine. 04-07.

Bovo G., Comuzi M., DeMas S., Ceschia G., Giorgetti G., Giacometti P., Cappellozza E. 1993. Isolamento di un agente virale irido-like da pesce gatto (Ictalurus melas) dallevamento. Bollettino Societa Italiana di Patologia Ittica 11:3-10.

Brand MD., Hill RD., Brenes R., Chaney JC., Wilkes RP., Grayfer L., Miller DL., Gray MJ. 2016. Water Temperature Affects Susceptibility to Ranavirus. EcoHealth 13:350-359. DOI: 10.1007/s10393-016-1120-1.

Brenes R., Gray MJ., Waltzek TB., Wilkes RP., Miller DL. 2014. Transmission of ranavirus between ectothermic vertebrate hosts. PLoS One 9:e92476. DOI: 10.1371/journal.pone.0092476.

Brenes R., Miller DL., Waltzek TB., Wilkes RP., Tucker JL., Chaney JC., Hardman RH., Brand MD., Huether RR., Gray MJ. 2014. Susceptibility of fish and turtles to three ranaviruses isolated from different ectothermic vertebrate classes. J Aquat Anim Health 26:118-126. DOI: $10.1080 / 08997659.2014 .886637$.

Brunner J., Storfer A., Gray M., Hoverman J. 2015. Ranavirus Ecology and Evolution: From Epidemiology to Extinction. In: Gray MJ, Chinchar VG eds. Ranaviruses. Springer International Publishing, 71-104. DOI: 10.1007/978-3-319-13755-1_4.

Butkus CE., Allender MC., Phillips CA., Adamovicz LA. 2017. Detection of ranavirus using bone marrow harvested from mortality events in eastern box turtles (Terrapene carolina carolina). Journal of Zoo and Wildlife Medicine 48:1210-1214. DOI: 10.1638/2017-0098.1.

Chattopadhyay S., Sinha NK., Banerjee S., Roy D., Chattopadhyay D., Roy S. 2006. Small cationic protein from a marine turtle has $\beta$-defensin-like fold and antibacterial and antiviral activity. Proteins: Structure, Function, and Bioinformatics 64:524-531. DOI: 10.1002/prot.20963. 
617

618

619

620

621

622

623

624

625

626

627

628

629

630

631

632

633

634

635

636

637

638

639

640

641

642

643

644

645

646

647

648

649

650

651

652

653

654

655

656

657

658

659

660

661

662

663

664

665

666
Chen G., Robert J. 2011. Antiviral immunity in amphibians. Viruses 3:2065-2086. DOI: 10.3390/v3112065.

Chen $Z$ xian., Zheng J chuan., Jiang $Y$ lin. 1999. A new iridovirus isolated from soft-shelled turtle. Virus Research 63:147-151. DOI: 10.1016/S0168-1702(99)00069-6.

Chinchar VG., Waltzek TB. 2014. Ranaviruses: not just for frogs. PLoS Pathog 10:e1003850. DOI: 10.1371/journal.ppat.1003850.

Chinchar VG., Hick P., Ince IA., Jancovich JK., Marschang R., Qin Q., Subramaniam K., Waltzek TB., Whittington R., Williams T., Zhang Q-Y. 2017. ICTV Virus Taxonomy Profile: Iridoviridae. Journal of General Virology 98:890-891. DOI: 10.1099/jgv.0.000818.

Claytor SC., Subramaniam K., Landrau-Giovannetti N., Chinchar VG., Gray MJ., Miller DL., Mavian C., Salemi M., Wisely S., Waltzek TB. 2017. Ranavirus phylogenomics: Signatures of recombination and inversions among bullfrog ranaculture isolates. Virology 511:330-343. DOI: $10.1016 /$ j.virol.2017.07.028.

de Jesús Forzán M., Jones KM., Vanderstichel RV., Wood J., Kibenge FSB., Kuiken T., Wirth W., Ariel E., Daoust P-Y. 2015. Clinical signs, pathology and dose-dependent survival of adult wood frogs, Rana sylvatica, inoculated orally with Frog Virus 3 (Ranavirus sp, Iridoviridae). Journal of General Virology:vir. 0.000043.

DeVoe R., Geissler K., Elmore S., Rotstein D., Lewbart G., Guy J. 2004. Ranavirus-associated morbidity and mortality in a group of captive eastern box turtles (Terrapene carolina carolina). Journal of Zoo and Wildlife Medicine 35:534-543. DOI: 10.1638/03-037.

Duffus ALJ., Waltzek TB., Stöhr AC., Allender MC., Gotesman M., Whittington RJ., Hick P., Hines MK., Marschang RE. 2015. Distribution and host range of ranaviruses. In: Ranaviruses. Springer, 9-57.

Ferguson SD., Johnson AJ., Waltzek T., Rice AD., Childress AL., James F.X. WJ. 2014. In Vitro Efficacy of Cidofovir and Acyclovir against Frog Virus 3. In: Proceedings Association of Reptilian and Amphibian Veterinarians. 38.

Ferronato BO., Merchant ME., Marques TS., Verdade LM. 2009. Characterization of innate immune activity in Phrynops geoffroanus (Testudines: Chelidae). Zoologia (Curitiba, Impresso) 26. DOI: 10.1590/s1984-46702009000400020.

Fu JP., Chen SN., Zou PF., Huang B., Guo Z., Zeng LB., Qin QW., Nie P. 2014. IFN-y in turtle: Conservation in sequence and signalling and role in inhibiting iridovirus replication in Chinese soft-shelled turtle Pelodiscus sinensis. Developmental \& Comparative Immunology 43:87-95. DOI: 10.1016/j.dci.2013.11.001.

Gibbons JW., Scott DE., Ryan TJ., Buhlmann KA., Tuberville TD., Metts BS., Greene JL., Mills T., Leiden Y., Poppy S. 2000. The Global Decline of Reptiles, Déjà Vu Amphibians. Bioscience 50:653-666.

Gobbo F., Cappellozza E., Pastore M., Bovo G. 2010. Susceptibility of black bullhead Ameiurus melas to a panel of ranavirus isolates. Diseases of Aquatic Organisms 90:167-174. DOI: 10.3354/dao02218.

Goodman RM., Hargadon KM., Carter ED. 2018. Detection of Ranavirus in Eastern Fence Lizards and Eastern Box Turtles in Central Virginia. Northeastern Naturalist 25:391-398. DOI: 10.1656/045.025.0306.

Goodman RM., Miller DL., Ararso YT. 2013. Prevalence of Ranavirus in Virginia Turtles as Detected by Tail-Clip Sampling Versus Oral-Cloacal Swabbing. Northeastern Naturalist 20:325-332. DOI: 10.1656/045.020.0208.

Granoff A., Came P., Rafferty K. 1965. The isolation and properties of viruses from rana pipiens: their possible relationship to the renal adenocarcinoma of the leopard frog. Annals of the New York Academy of Sciences 5176:237-255. DOI: 10.1111/j.1749-6632.1965.tb14278.x. Gray MJ., Miller DL., Hoverman JT. 2009. Ecology and pathology of amphibian ranaviruses. Diseases of Aquatic Organisms 87:243-266. DOI: 10.3354/dao02138. 
667

668

669

670

671

672

673

674

675

676

677

678

679

680

681

682

683

684

685

686

687

688

689

690

691

692

693

694

695

696

697

698

699

700

701

702

703

704

705

706

707

708

709

710

711

712

713

714

715

716
Gray MJ., Chinchar G V. 2015. Ranaviruses: Lethal Pathogens of Ectothermic Vertebrates. DOI: 10.1007/978-3-319-13755-1.

Grayfer L., Edholm E-S., De Jesús Andino F., Chinchar VG., Robert J. 2015. Ranavirus Host Immunity and Immune Evasion. In: Gray MJ, Chinchar VG eds. Ranaviruses. Springer International Publishing, 141-170. DOI: 10.1007/978-3-319-13755-1_6.

Haislip NA., Hoverman JT., Miller DL., Gray MJ. 2012. Natural stressors and disease risk: does the threat of predation increase amphibian susceptibility to ranavirus? Canadian Journal of Zoology 90:893-902. DOI: 10.1139/z2012-060.

Hall EM., Crespi EJ., Goldberg CS., Brunner JL. 2016. Evaluating environmental DNA-based quantification of ranavirus infection in wood frog populations. Molecular Ecology Resources 16:423-433. DOI: 10.1111/1755-0998.12461.

HANLON SM., HENSON JR., PATILLIO B., WEEKS D., KERBY JL., MOORE JE. 2016. No Occurrence of Ranaviruses in Reptiles from Wapanocca National Wildlife Refuge in Arkansas, USA. Herpetological Review 47:606-607.

Hardman RH., Sutton WB., McGinnity D., Irwin KJ., Reinsch S., Fitzpatrick B., Colclough P., Souza M., Freake M., Gray MJ., Miller DL. 2013. Prevalence of Ranavirus and Batrachochytrium dendrobatidis in Hellbenders of Tennessee and Arkansas.

Heldstab A., Bestetti G. 1982. Spontaneous Viral Hepatitis in a Spur-Tailed Mediterranean Land Tortoise (Testudo hermanni). The Journal of Zoo Animal Medicine 13:113. DOI: 10.2307/20094592.

Hick PM., Subramaniam K., Thompson P., Whittington RJ., Waltzek TB. 2016. Complete Genome Sequence of a Bohle iridovirus Isolate from Ornate Burrowing Frogs (Limnodynastes ornatus) in Australia. Genome Announcements 4:e00632-16. DOI: 10.1128/genomeA.00632-16.

Horner R. 1988. Poxvirus in farmed Nile crocodiles. Veterinary Record 122:459-462. DOI: 10.1136/vr.122.19.459.

Hyatt AD., Eaton BT., Hengstberger S., Russel G. 1991. Epizootic haematopoietic necrosis virus: detection by ELISA, immunohistochemistry and immunoelectron-microscopy. Journal of Fish Diseases 14:605-617. DOI: 10.1111/j.1365-2761.1991.tb00619.x.

Hyatt AD., Williamson M., Coupar BE., Middleton D., Hengstberger SG., Gould AR., Selleck P., Wise TG., Kattenbelt J., Cunningham AA., Lee J. 2002. First identification of a ranavirus from green pythons (Chondropython viridis). J Wildl Dis 38:239-252. DOI: 10.7589/00903558-38.2.239.

Hyndman T., Marschang RE. 2017. Infectious Diseases and Immunology. In: Reptile Medicine and Surgery in Clinical Practice. 197-216.

Jacobson ER., Gaskin JM., Flanagan JP., Odum RA. 1991. Antibody Responses of Western Diamondback Rattlesnakes (Crotalus atrox) to Inactivated Ophidian Paramyxovirus Vaccines. Journal of Zoo and Wildlife Medicine 22:184-190.

Jancovich JK., Bremont M., Touchman JW., Jacobs BL. 2010. Evidence for Multiple Recent Host Species Shifts among the Ranaviruses (Family Iridoviridae). Journal of Virology 84:2636-2647. DOI: 10.1128/JVI.01991-09.

Jancovich JK., Qin Q., Zhang Q-Y., Chinchar VG. 2015. Ranavirus Replication: Molecular, Cellular, and Immunological Events. In: Gray MJ, Chinchar VG eds. Ranaviruses. Cham: Springer International Publishing, 105-139. DOI: 10.1007/978-3-319-13755-1_5.

Jensen BB., Holopainen R., Tapiovaara H., Ariel E. 2011. Susceptibility of pike-perch Sander lucioperca to a panel of ranavirus isolates. Aquaculture 313:24-30. DOI: 10.1016/j.aquaculture.2011.01.036.

Johnson AJ., Pessier AP., Jacobson ER. 2007. Experimental transmission and induction of ranaviral disease in Western Ornate box turtles (Terrapene ornata ornata) and red-eared sliders (Trachemys scripta elegans). Vet Pathol 44:285-297. DOI: 10.1354/vp.44-3-285. 
717

718

719

720

721

722

723

724

725

726

727

728

729

730

731

732

733

734

735

736

737

738

739

740

741

742

743

744

745

746

747

748

749

750

751

752

753

754

755

756

757

758

759

760

761

762

763

764

765

766

767

Johnson AJ., Pessier AP., Wellehan JF., Childress A., Norton TM., Stedman NL., Bloom DC., Belzer W., Titus VR., Wagner R., Brooks JW., Spratt J., Jacobson ER. 2008. Ranavirus infection of free-ranging and captive box turtles and tortoises in the United States. $J$ Wildl Dis 44:851-863. DOI: 10.7589/0090-3558-44.4.851.

Johnson AJ., Wendland L., Norton TM., Belzer B., Jacobson ER. 2010. Development and use of an indirect enzyme-linked immunosorbent assay for detection of iridovirus exposure in gopher tortoises (Gopherus polyphemus) and eastern box turtles (Terrapene carolina carolina). Vet Microbiol 142:160-167. DOI: 10.1016/j.vetmic.2009.09.059.

Keller JM., McClellan-Green PD., Kucklick JR., Keil DE., Peden-Adams MM. 2006. Effects of organochlorine contaminants on loggerhead sea turtle immunity: Comparison of a correlative field study and in vitro exposure experiments. Environmental Health Perspectives 114:70-76. DOI: 10.1289/ehp.8143.

Kerby JL., Hart AJ., Storfer A. 2011. Combined Effects of Virus, Pesticide, and Predator Cue on the Larval Tiger Salamander (Ambystoma tigrinum). EcoHealth 8:46-54. DOI: 10.1007/s10393-011-0682-1.

Kimble SJA., Johnson AJ., Williams RN., Hoverman JT. 2017. A Severe Ranavirus Outbreak in Captive, Wild-Caught Box Turtles. EcoHealth 14:810-815. DOI: 10.1007/s10393-017-12638.

Kimble SA., Karna A., Johnson A., Hoverman J., Williams R. 2014. Mosquitoes as a Potential Vector of Ranavirus Transmission in Terrestrial Turtles. EcoHealth:1-5. DOI: 10.1007/s10393-014-0974-3.

Kischinovsky M., Raftery A., Sawmy S. 2017. Husbandry and Nutrition. In: Reptile Medicine and Surgery in Clinical Practice. 45-60.

Kolesnik E., Obiegala A., Marschang RE. 2017. Detection of Mycoplasma spp., herpesviruses, topiviruses, and ferlaviruses in samples from chelonians in Europe. Journal of Veterinary Diagnostic Investigation 29:820-832. DOI: 10.1177/1040638717722387.

Langdon JS. 1989. Experimental transmission and pathogenicity of epizootic haematopoietic necrosis virus (EHNV) in redfin perch, Perca fluviatilis L., and 11 other teleosts. Journal of Fish Diseases 12:295-310. DOI: DOI: 10.1111/j.1365-2761.1989.tb00318.x.

Langdon JS., Humphrey JD., Williams LM., Hyatt AD., Westbury HA. 1986. First virus isolation from Australian fish: an iridovirus-like pathogen from redfin perch, Perca fluviatilis $\mathrm{L}$. Journal of Fish Diseases 9:263-268. DOI: 10.1111/j.1365-2761.1986.tb01011.x.

Lefkowitz EJ., Dempsey DM., Hendrickson RC., Orton RJ., Siddell SG., Smith DB. 2018. Virus taxonomy: the database of the International Committee on Taxonomy of Viruses (ICTV). Nucleic Acids Research 46:D708-D717.

Leung WTM., Thomas-Walters L., Garner TWJ., Balloux F., Durrant C., Price SJ. 2017. A quantitative-PCR based method to estimate ranavirus viral load following normalisation by reference to an ultraconserved vertebrate target. Journal of Virological Methods 249:147155. DOI: 10.1016/j.jviromet.2017.08.016.

Li P., Zhou L., Yu Y., Yang M., Ni S., Wei S., Qin Q. 2015. Characterization of DNA aptamers generated against the soft-shelled turtle iridovirus with antiviral effects. BMC Veterinary Research 11:1-11. DOI: 10.1186/s12917-015-0559-6.

Maclaine A., Mashkour N., Scott J., Ariel E. 2018. Susceptibility of eastern water dragons Intellagama lesueurii lesueurii to Bohle iridovirus. Diseases of Aquatic Organisms 127:97105. DOI: 10.3354/dao03193.

Maniero GD., Morales H., Gantress J., Robert J. 2006. Generation of a long-lasting, protective, and neutralizing antibody response to the ranavirus FV3 by the frog Xenopus.

Developmental \& Comparative Immunology 30:649-657. DOI: 10.1016/j.dci.2005.09.007.

Marschang RE., Becher P., Posthaus H., Wild P., Thiel HJ., Muller-Doblies U., Kalet EF., Bacciarini LN. 1999. Isolation and characterization of an iridovirus from Hermann's tortoises (Testudo hermanni). Arch Virol 144:1909-1922. 
768

769

770

771

772

773

774

775

776

777

778

779

780

781

782

783

784

785

786

787

788

789

790

791

792

793

794

795

796

797

798

799

800

801

802

803

804

805

806

807

808

809

810

811

812

813

814

815

816

817

818
Marschang RE., Milde K., Bellavista M. 2001. Virus isolation and vaccination of Mediterranean tortoises against a chelonid herpesvirus in a chronically infected population in Italy. Deutsche Tierarztliche Wochenschrift 108:376-379.

Marschang RE., Braun S., Becher P. 2005. Isolation of a ranavirus from a gecko (Uroplatus fimbriatus). Journal of zoo and wildlife medicine : official publication of the American Association of Zoo Veterinarians 36:295-300. DOI: 10.1638/04-008.1.

Marschang RE., Stöhr AC., Allender MC. 2016. Ranaviruses of reptiles - An increasing problem. Meddings Jl. 2011. Revelations in reptilian immunology : serology and sources of variation.

Merchant ME., Pallansch M., Paulman RL., Wells JB., Nalca A., Ptak R. 2005. Antiviral activity of serum from the American alligator (Alligator mississippiensis). Antiviral Research 66:3538. DOI: 10.1016/j.antiviral.2004.12.007.

Merchant M., Hammack T., Sanders P., Dronette J. 2006. Rapid and Inexpensive Method for the Spectroscopic Determination of Innate Immune Activity of Crocodilians. Spectroscopy Letters 39:337-343. DOI: 10.1080/00387010600781290.

Merchant M., Henry D., Falconi R., Muscher B., Bryja J. 2012. Characterization of serum complement activity in serum of the Komodo dragon (Varanus komodoensis). Advances in Biological Chemistry 02:353-359. DOI: 10.4236/abc.2012.24043.

Miller D., Pessier A., Hick P., Whittington R. 2015. Comparative Pathology of Ranaviruses and Diagnostic Techniques. In: Gray MJ, Chinchar VG eds. Ranaviruses. Springer International Publishing, 171-208. DOI: 10.1007/978-3-319-13755-1_7.

Mohan K., Foggin CM., Muvavarirwa P., Honywill J. 1997. Vaccination of farmed crocodiles (Crocodylus niloticus) against Mycoplasma crocodyli infection. Veterinary Record 141:476. DOI: 10.1136/vr.141.18.476.

Munro J., Bayley AE., McPherson NJ., Feist SW. 2016. Survival of Frog Virus 3 in Freshwater and Sediment from an English Lake. Journal of Wildlife Diseases 52:138-142. DOI: 10.7589/2015-02-033.

Nazir J., Spengler M., Marschang RE. 2012. Environmental persistence of amphibian and reptilian ranaviruses. Dis Aquat Organ 98:177-184. DOI: 10.3354/dao02443.

OIE (World Organisation for Animal Health). 2012. Chapter 2.1.2 Infection with ranavirus. In: Manual of diagnostic tests for aquatic animals (World Organisation for Animal Health).

Pallister Gould, A., Harrison, D., Hyatt, A., Jancovich, J., Heine, H., J. 2007. Development of real-time PCR assays for the detection and differentiation of Australian and European ranaviruses. Journal of Fish Diseases 30:427-438.

Perpiñán D., Blas-Machado U., Sánchez S., Miller DL. 2016. Concurrent Phaeohyphomycosis and Ranavirus Infection in an Eastern Box Turtle (Terrapene carolina) in Athens, Georgia, USA. Journal of Wildlife Diseases 52:742-745. DOI: 10.7589/2014-08-195.

Polakiewicz FJ., Goodman RM. 2013. The effects of environmental stressors and the pathogen Ranavirus on survival and health of juvenile freshwater turtles. Hampden-Sydney College $J$ Sci 2:1-6.

Preecharram S., Jearranaiprepame P., Daduang S., Temsiripong Y., Somdee T., Fukamizo T., Svasti J., Araki T., Thammasirirak S. 2010. Isolation and characterisation of crocosin, an antibacterial compound from crocodile (Crocodylus siamensis) plasma. Animal Science Journal 81:393-401. DOI: 10.1111/j.1740-0929.2010.00752.x.

Price SJ., Ariel E., Maclaine A., Rosa GM., Gray MJ., Brunner JL., Garner TWJ. 2017. From fish to frogs and beyond: Impact and host range of emergent ranaviruses. Virology 511:272279. DOI: 10.1016/j.virol.2017.08.001.

Readel AM., Phillips C a., Wetzel MJ. 2008. Leech Parasitism in a Turtle Assemblage: Effects of Host and Environmental Characteristics. Copeia 2008:227-233. DOI: 10.1643/CH-06-212.

Reeve BC., Crespi EJ., Whipps CM., Brunner JL. 2013. Natural stressors and ranavirus susceptibility in larval wood frogs (Rana sylvatica). EcoHealth 10:190-200. DOI: 10.1007/s10393-013-0834-6. 
819

820

821

822

823

824

825

826

827

828

829

830

831

832

833

834

835

836

837

838

839

840

841

842

843

844

845

846

847

848

849

850

851

852

853

854

855

856

857

858

859

860

861

862

863

864

865

866

867

868

Reinauer S., Bohm R., Marschang RE. 2005. Inactivation of tortoise viruses in the environment. Journal of Herpetological Medicine and Surgery 15:10-15.

Rios FM., Zimmerman LM. 2015. Immunology of Reptiles. eLS:1-7. DOI: 10.1002/9780470015902.a0026260.

Robert J., Grayfer L., Edholm ES., Ward B., De Andino FJS. 2014. Inflammation-induced reactivation of the ranavirus frog VIRUS 3 in asymptomatic xenopus laevis. PLoS ONE 9. DOI: 10.1371/journal.pone.0112904.

Schloegel LM., Daszak P., Cunningham AA., Speare R., Hill B. 2010. Two amphibian diseases, chytridiomycosis and ranaviral disease, are now globally notifiable to the World Organization for Animal Health (OIE): an assessment. Diseases of Aquatic Organisms 92:101-108. DOI: 10.3354/dao02140.

Siddall ME., Desser SS. 1992. Alternative leech vectors for frog and turtle trypanosomes. The Journal of Parasitology 78:562-563. DOI: 10.2307/3283672.

Sim RR., Allender MC., Crawford LK., Wack AN., Murphy KJ., Mankowski JL., Bronson E. 2016. Ranavirus epizootic in captive eastern box turtles (Terrapene carolina carolina) with concurrent herpesvirus and mycoplasma infection: management and monitoring. Journal of Zoo and Wildlife Medicine 47:256-270. DOI: 10.1638/2015-0048.1.

Soltanian S. 2016. Effect of atrazine on immunocompetence of red-eared slider turtle (Trachemys scripta). Journal of Immunotoxicology 13:804-809. DOI: 10.1080/1547691X.2016.1195463.

Stohr AC., Blahak S., Heckers KO., Wiechert J., Behncke H., Mathes K., Gunther P., Zwart P., Ball I., Ruschoff B., Marschang RE. 2013. Ranavirus infections associated with skin lesions in lizards. Veterinary Research 44:84. DOI: 10.1186/1297-9716-44-84.

Stöhr AC., López-Bueno A., Blahak S., Caeiro MF., Rosa GM., Alves de Matos AP., Martel A., Alejo A., Marschang RE. 2015. Phylogeny and Differentiation of Reptilian and Amphibian Ranaviruses Detected in Europe. PLOS ONE 10:e0118633. DOI: 10.1371/journal.pone.0118633.

Subramaniam K., Toffan A., Cappellozza E., Steckler NK., Olesen NJ., Ariel E., Waltzek TB. 2016. Genomic Sequence of a Ranavirus Isolated from Short-Finned Eel (Anguilla australis). Genome Announcements 4:e00843-16. DOI: 10.1128/genomeA.00843-16.

Tamukai K., Tokiwa T., Kobayashi H., Une Y. 2016. Ranavirus in an outbreak of dermatophilosis in captive inland bearded dragons (Pogona vitticeps). Veterinary Dermatology 27:99-e28. DOI: 10.1111/vde.12288.

Uetz P., Freed P., Hošek J. 2016.The Reptile Database. Available at http://www.reptiledatabase.org (accessed February 2, 2017).

van Hoek M. 2014. Antimicrobial peptides in reptiles. Pharmaceuticals 7:723-753. DOI: 10.3390/ph7060723.

Watermolen DJ. 1996. Notes on the leech Desserobdella picta (Hirudinea: Glossiphoniidae). Journal of Freshwater Ecology 11:211-217. DOI: 10.1080/02705060.1996.9663480.

Westhouse RA., Jacobson ER., Harris RK., Winter KR., Homer BL. 1996. Respiratory and pharyngo-esophageal iridovirus infection in a gopher tortoise (Gopherus polyphemus). Journal of wildlife diseases 32:682-686. DOI: 10.7589/0090-3558-32.4.682.

Whittington RJ., Becker JA., Dennis MM. 2010. Iridovirus infections in finfish - critical review with emphasis on ranaviruses. Journal of Fish Diseases 33:95-122. DOI: 10.1111/j.13652761.2009.01110.x.

Whittington RJ., Hyatt AD., Kearns C., Hyatt AD., Hengstberger S., Rutzou T. 1996. Spread of epizootic haematopoietic necrosis virus (EHNV) in redfin perch (Perca fluviatilis) in southern Australia. Australian Veterinary Journal 73:112-114.

Widal S. 1897. Influence de l'organisme sur les propriét'es par les humures du fait de l'infection (l'agglutination chez quelques animaux à sang froid). CR Soc. Biol., Paris 49:1047-1050. 
869 Winzeler ME., Haskins DL., Lance SL., Tuberville TD. 2018. Survey of aquatic turtles on the savannah river site, South Carolina, USA, for prevalence of ranavirus. Journal of Wildlife Diseases 54:138-141. DOI: 10.7589/2016-08-182.

Wobeser GA. 2007. Disease in wild animals: Investigation and management. DOI: 10.1007/9783-540-48978-8.

Yang Z., Pan H., Sun H. 2007. The immune response and protective efficacy of oral alginate microparticle Aeromonas sobria vaccine in soft-shelled turtles (Trionyx sinensis). Veterinary Immunology and Immunopathology 119:299-302. DOI: 10.1016/j.vetimm.2007.05.011.

Zhang M., Yang JX., Lin XM., Zhu CH., He JQ., Liu H., Lin TL. 2010. A double antibody sandwich enzyme-linked immunosorbent assay for detection of soft-shelled turtle iridovirus antigens. Journal of Virological Methods 167:193-198. DOI: 10.1016/j.jviromet.2010.04.004.

Zimmerman LM., Vogel LA., Bowden RM. 2010. Understanding the vertebrate immune system: insights from the reptilian perspective. Journal of Experimental Biology 213:661-671. DOI: 10.1242/jeb.038315.

Zimmerman LM., Vogel LA., Edwards KA., Bowden RM. 2010. Phagocytic B cells in a reptile. Biol Lett 6:270-273 


\section{Figure 1}

Trend in the number of ranavirus papers referring to reptiles.

Ratio of ranavirus papers ( $n=449)$ using the terms 'reptile' vs 'amphibian' in their title or abstract, showing the increase in the relative percent of publications referring to reptiles. A value of $100 \%$ would indicate the same number of Ranavirus papers use the term 'reptile' as 'amphibian'. Solid line is the linear trend line fitted with 95\% confidence interval (shaded area). 


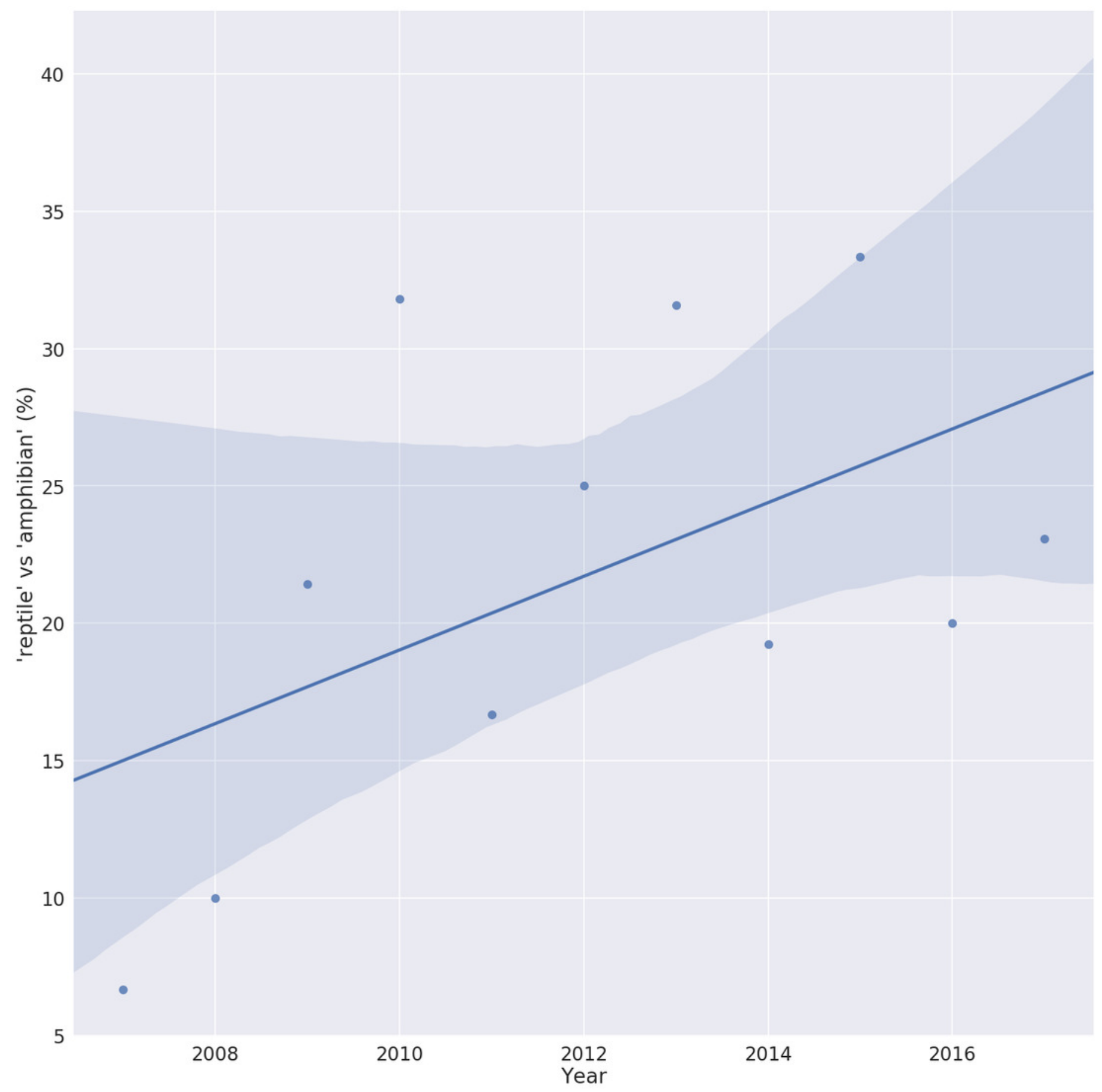




\section{Table $\mathbf{1}$ (on next page)}

Representative reptilian ranaviral pathogenesis.

This table includes only cases of moribund reptiles where sufficient clinical description was given. $A=$ abscess, $A n=$ anorexia,$C=$ conjunctivitis, $C N=$ central nervous disorders, $D A=$ decreased-activity/depression/lethargy, $\mathrm{D}=$ discharge, $\mathrm{E}=$ oedema, $\mathrm{H}=$ haemorrhage, $\mathrm{I}=$ inflammation, $\mathrm{L}=$ lesion, $\mathrm{N}=$ necrosis, $\mathrm{T}=$ thrombi, $\mathrm{U}=$ ulceration. 


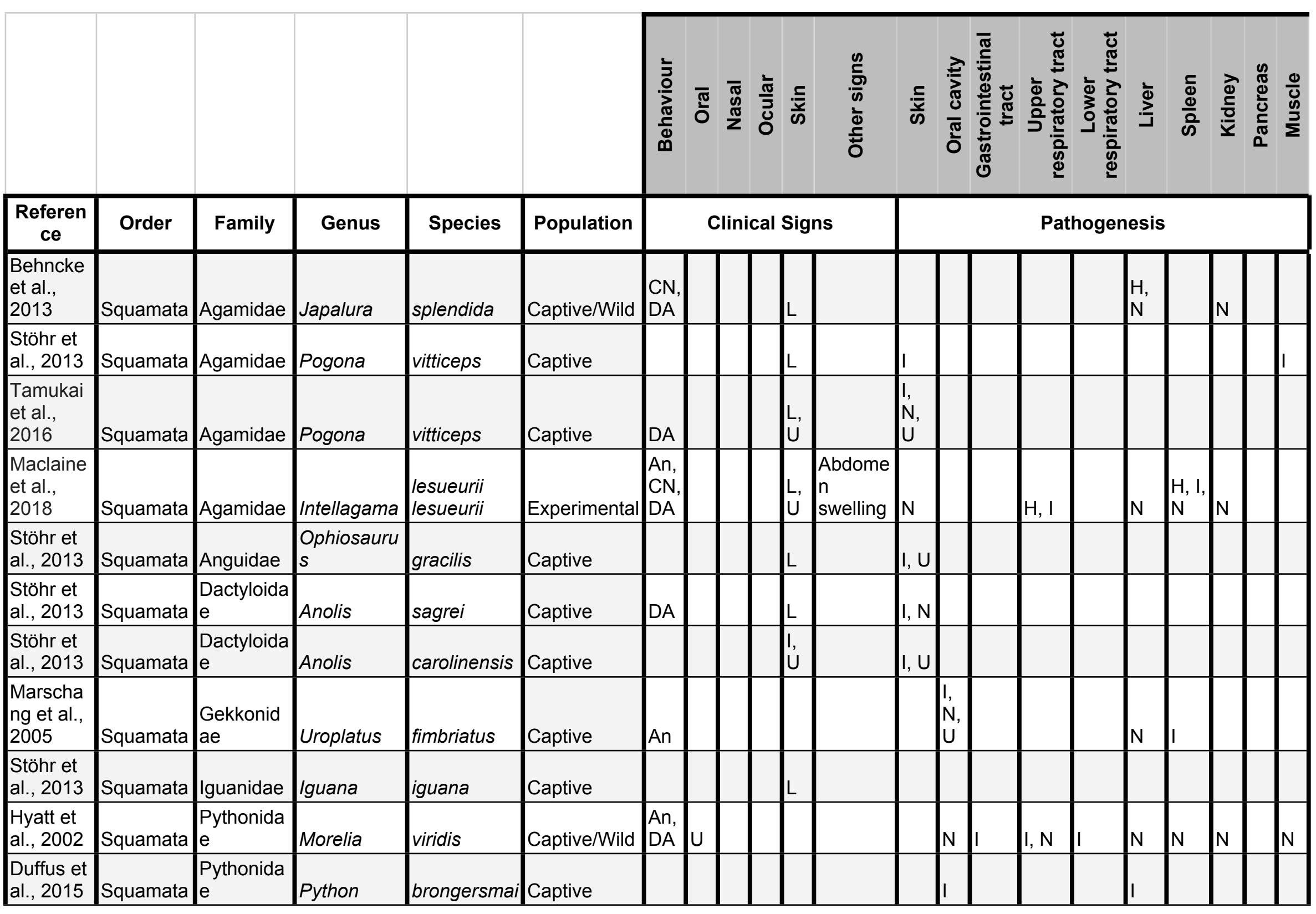




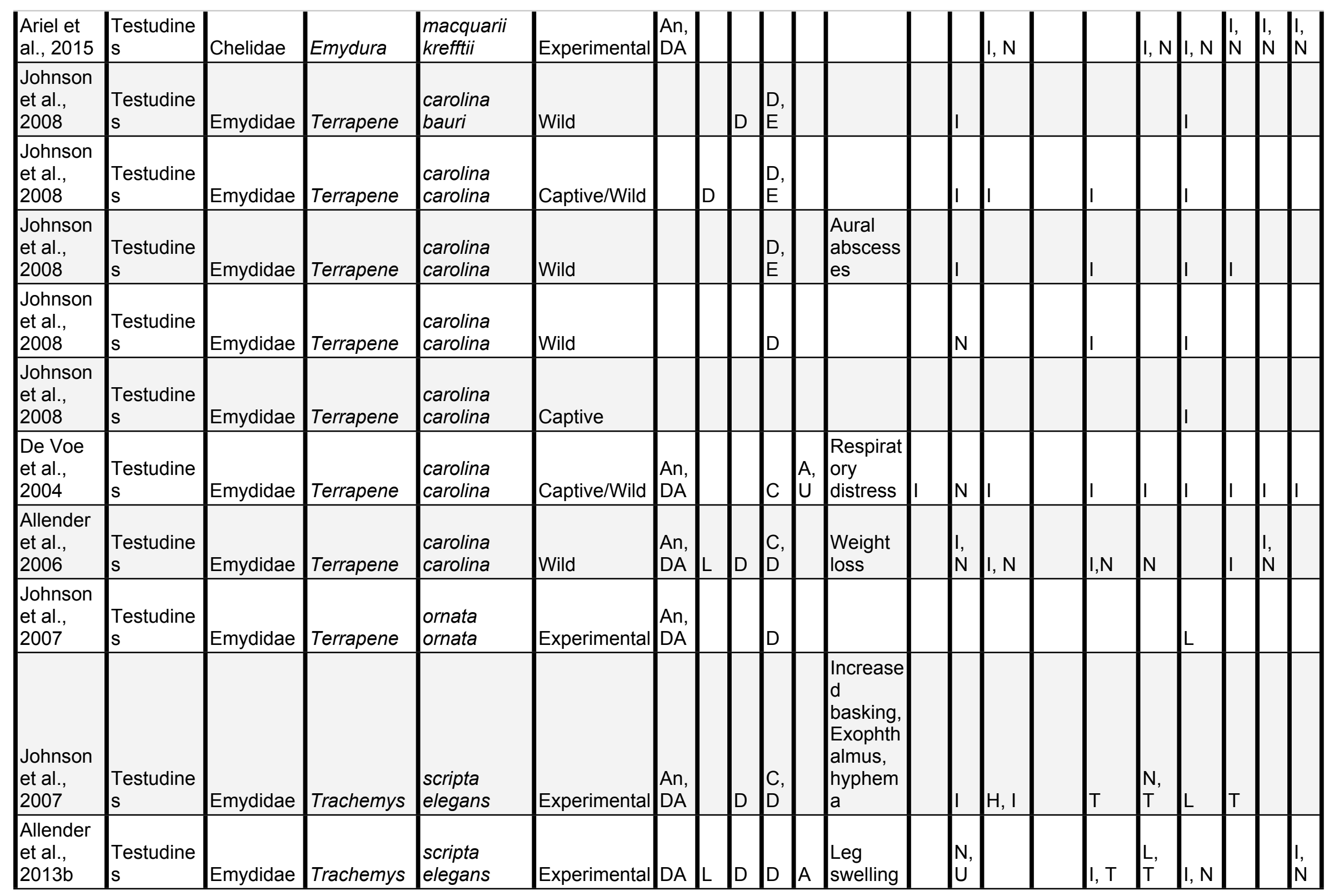




\begin{tabular}{|c|c|c|c|c|c|c|c|c|c|c|c|c|c|c|c|c|}
\hline $\begin{array}{l}\text { Benetka } \\
\text { et al., } \\
2007\end{array}$ & $\begin{array}{l}\text { Testudine } \\
\text { s }\end{array}$ & $\begin{array}{l}\text { Testudinid } \\
\text { ae }\end{array}$ & \begin{tabular}{|l} 
Stigmochel \\
ys \\
(Geochelon \\
e)
\end{tabular} & pardalis & Captive & $\begin{array}{l}\text { An, } \\
\text { DA }\end{array}$ & D 1 & I & & & N, & & I & & & \\
\hline $\begin{array}{l}\text { Marscha } \\
\text { ng et } \\
\text { al.,1999 }\end{array}$ & $\begin{array}{l}\text { Testudine } \\
\mathrm{s}\end{array}$ & $\begin{array}{l}\text { Testudinid } \\
\text { ae }\end{array}$ & Testudo & hermanni & Captive & & & & & & & I, N & & II, N & & \\
\hline $\begin{array}{l}\text { Blahak \& } \\
\text { Uhlenbro } \\
\text { k, } 2010\end{array}$ & $\begin{array}{l}\text { Testudine } \\
\text { s }\end{array}$ & $\begin{array}{l}\text { Testudinid } \\
\text { ae }\end{array}$ & Testudo & hermanni & Captive & & & & & $\begin{array}{l}\text { Emaciati } \\
\text { on }\end{array}$ & I & & & & & \\
\hline $\begin{array}{l}\text { Blahak \& } \\
\text { Uhlenbro } \\
\text { k, } 2010\end{array}$ & $\begin{array}{l}\text { Testudine } \\
\text { s }\end{array}$ & $\begin{array}{l}\text { Testudinid } \\
\text { ae }\end{array}$ & Testudo & kleinmanni & Captive & & & & & & I & & I & I & & \\
\hline $\begin{array}{l}\text { Blahak \& } \\
\text { Uhlenbro } \\
\text { k, } 2010\end{array}$ & $\begin{array}{l}\text { Testudine } \\
\text { s }\end{array}$ & $\begin{array}{l}\text { Testudinid } \\
\text { ae }\end{array}$ & Testudo & marginata & Captive & & & & & & I & & $\mathrm{N}$ & & & \\
\hline $\begin{array}{l}\text { Heldstab } \\
\& \\
\text { Bestetti, } \\
1982\end{array}$ & $\begin{array}{l}\text { Testudine } \\
\text { s }\end{array}$ & $\begin{array}{l}\text { Testudinid } \\
\text { ae }\end{array}$ & Testudo & hermanni & Captive & & & & & & & I, N & & II, N & $\mathrm{I}, \mathrm{N}$ & \\
\hline $\begin{array}{l}\text { Johnson } \\
\text { et al., } \\
2008 \\
\end{array}$ & $\begin{array}{l}\text { Testudine } \\
\text { s }\end{array}$ & $\begin{array}{l}\text { Testudinid } \\
\text { ae }\end{array}$ & Geochelone & platynota & Captive & & & $D C$ & C & $\begin{array}{l}\text { Neck } \\
\text { swelling }\end{array}$ & 1 & I, N & & & I & I \\
\hline $\begin{array}{l}\text { Johnson } \\
\text { et al., } \\
2008\end{array}$ & $\begin{array}{l}\text { Testudine } \\
\text { s }\end{array}$ & $\begin{array}{l}\text { Testudinid } \\
\text { ae }\end{array}$ & Gopherus & polyphemus & Wild & & & $\mathrm{D}$ & $\begin{array}{l}\mathrm{C}, \\
\mathrm{D}, \\
\mathrm{E}\end{array}$ & & I & & & & I & I \\
\hline $\begin{array}{l}\text { Westhou } \\
\text { se et al., } \\
1996\end{array}$ & $\begin{array}{l}\text { Testudine } \\
\text { s }\end{array}$ & $\begin{array}{l}\text { Testudinid } \\
\text { ae }\end{array}$ & Gopherus & polyphemus & Wild & DA & & $D[$ & D & $\begin{array}{l}\text { Respirat } \\
\text { ory } \\
\text { disease }\end{array}$ & & I & $\mathrm{U}_{\mathrm{U}}^{\mathrm{N}, \mathrm{N}}$ & & & \\
\hline $\begin{array}{l}\text { Chen et } \\
\text { al., } 1999\end{array}$ & $\begin{array}{l}\text { Testudine } \\
\text { s }\end{array}$ & $\begin{array}{l}\text { Trionychid } \\
\text { ae }\end{array}$ & Pelodiscus & sinensis & $\begin{array}{l}\text { Captive/ } \\
\text { Experimental }\end{array}$ & & & & & $\begin{array}{l}\text { Red } \\
\text { neck, } \\
\text { neck } \\
\text { swelling }\end{array}$ & & & & $\mathrm{H}$ & & \\
\hline
\end{tabular}

